
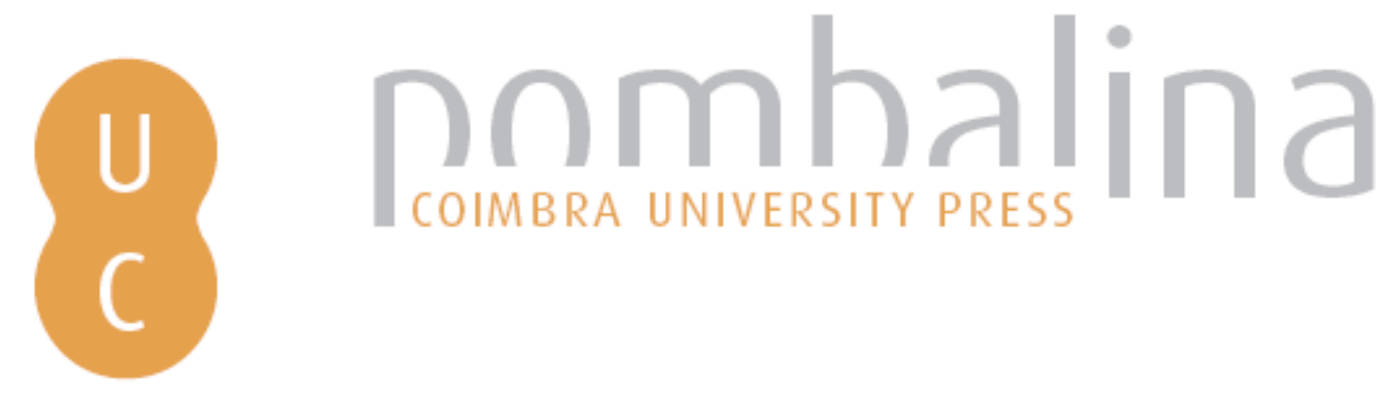

\title{
The impact of a crisis in a cost-benefit analysis: What has changed in the Douro Interior sub-concession economic evaluation?
}

Autor(es): $\quad$ Filipe, Sandrina; Godinho, Pedro; Dias, Joana

Publicado por: Imprensa da Universidade de Coimbra

URL

persistente: URI:http://hdl.handle.net/10316.2/38154

DOI: $\quad$ DOI:http://dx.doi.org/10.14195/978-989-26-1039-9_8

Accessed : $\quad$ 26-Apr-2023 15:01:25

A navegação consulta e descarregamento dos títulos inseridos nas Bibliotecas Digitais UC Digitalis, UC Pombalina e UC Impactum, pressupõem a aceitação plena e sem reservas dos Termos e Condições de Uso destas Bibliotecas Digitais, disponíveis em https://digitalis.uc.pt/pt-pt/termos.

Conforme exposto nos referidos Termos e Condições de Uso, o descarregamento de títulos de acesso restrito requer uma licença válida de autorização devendo o utilizador aceder ao(s) documento(s) a partir de um endereço de IP da instituição detentora da supramencionada licença.

Ao utilizador é apenas permitido o descarregamento para uso pessoal, pelo que o emprego do(s) título(s) descarregado(s) para outro fim, designadamente comercial, carece de autorização do respetivo autor ou editor da obra.

Na medida em que todas as obras da UC Digitalis se encontram protegidas pelo Código do Direito de Autor e Direitos Conexos e demais legislação aplicável, toda a cópia, parcial ou total, deste documento, nos casos em que é legalmente admitida, deverá conter ou fazer-se acompanhar por este aviso.

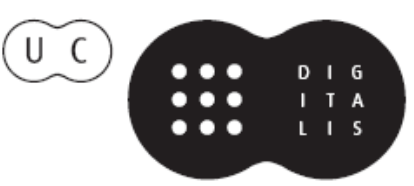


IMPRENSA DA UNIVERSIDADE DE COIMBRA

COIMBRA UNIVERSITY PRESS

\section{ASSESSMENT \\ METHODOLOGIES}

ENERGY, MOBILITY AND OTHER

REAL WORLD APPLICATION

\section{PEDRO GODINHO \\ JOANA DIAS}

EDITORS

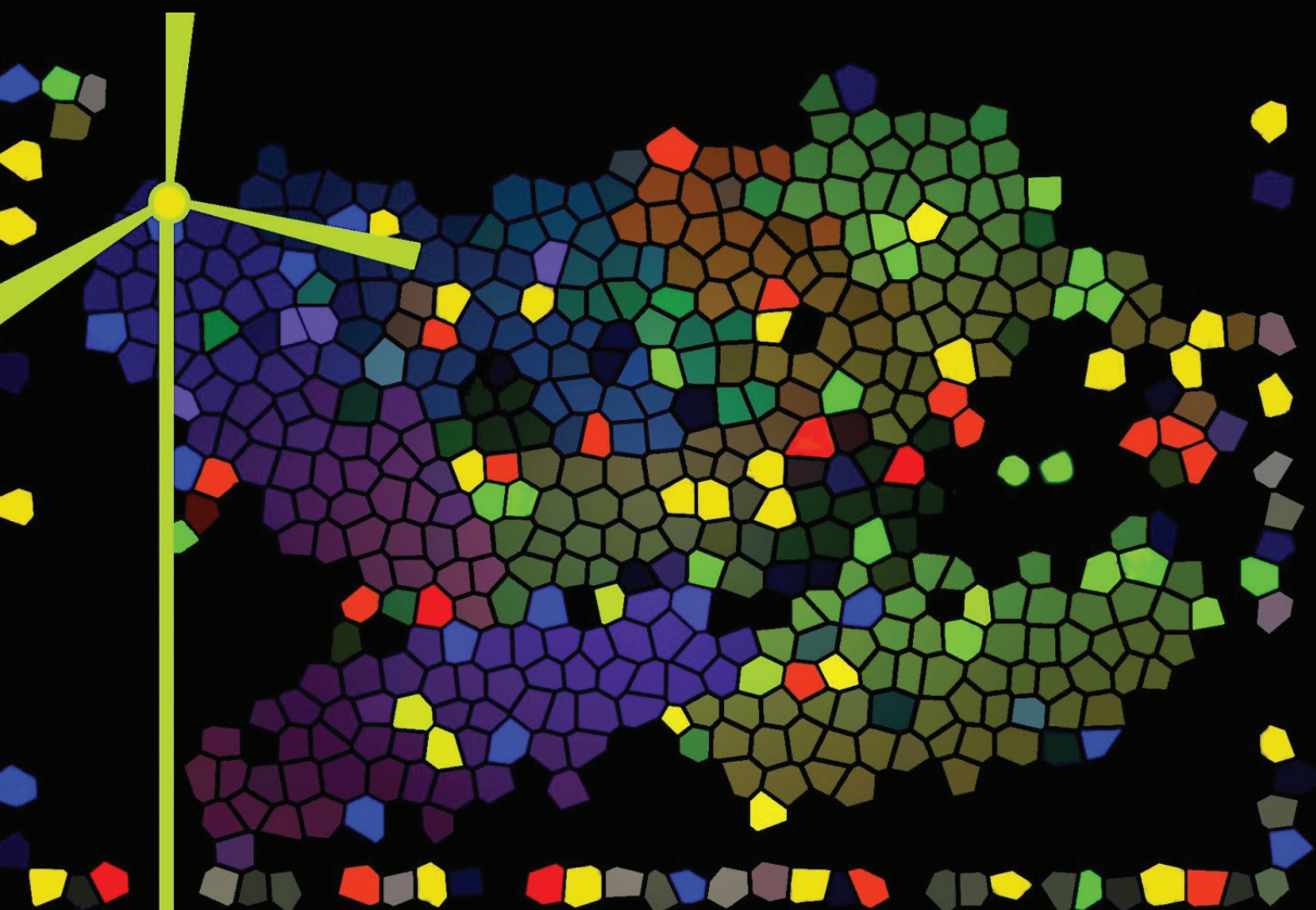




\title{
THE IMPACT OF A CRISIS IN A COST-BENEFIT ANALYSIS: WHAT HAS CHANGED IN THE DOURO INTERIOR SUB-CONCESSION ECONOMIC EVALUATION?
}

\author{
Sandrina Filipe, Pedro Godinho and Joana Dias ${ }^{1}$
}

\begin{abstract}
In this paper we analyse the impact of a crisis in the economic evaluation of a road infrastructure. We consider the Douro Interior sub-concession, awarded by the Portuguese government to a private consortium in 2008, and concluded in 2012. The government decision was based on economic analysis made on 2008, which concluded that the economic benefits of the infrastructure would be larger than its economic costs. Today there are some doubts whether it was really worthwhile to build the infrastructure, but any analysis based on the current situation must take into account that Portugal underwent a severe crisis with significant impact on its macro-economic indicators. The exercise we undertake consists of analysing what would be changed in the 2008 analysis if it would have been possible to foresee the macro-economic changes in the Portuguese situation. In order to perform this analysis, we use the economic evaluations published in 2008 and we update the macro-economic data according to the information available at the beginning of 2015. The resulting evaluation highlights the components of the analysis that would have been altered if the crisis and other macro-economic changes had been foreseen.

We conclude that the changes in the Portuguese macro-economic situation would be enough to justify the alteration of the recommendation produced by the economic evaluations. This highlights the importance of using methodologies that allow the incorporation of risk in the assessment of such projects, as well as the
\end{abstract}

\footnotetext{
1 University of Coimbra, Faculty of Economics

E-mails: sandrina.filipe@fe.uc.pt,pgodinho@fe.uc.pt, joana@fe.uc.pt
} 
explicit incorporation of the postponement option in the analysis. Additionally, it shows that some caution is necessary when performing ex-post analysis of economic studies: unforeseen changes in the macro-economic situation may be enough to alter the recommendation provided by such studies.

Keywords: Cost-Benefit Analysis; Highways and roads; Economic factors

\section{Introduction}

Over the last decades there has been a significant growth of the investment in road infrastructures in Portugal (Ferreira, 2013; Rosmaninho, 2010). Empirical studies show that such investment had positive impacts on employment, private investment and private output, and that it also contributed to increased labour productivity and purchasing power (Pereira \& Andraz, 2007).

In order to carry out such investments within the constraints of the government budget, Portuguese authorities adopted a funding method based on Public-Private Partnerships (PPP) and "shadow tolls", that is, tolls which are paid by the government instead of the user. Under this scheme, private companies are responsible for the design, construction, financing, operation and maintenance of the roads. In return, they are paid an amount that depends on the traffic volume, usually for a period of 30 years (Pereira \& Andraz, 2012).

The Douro Interior Sub-Concession was awarded on 2008 to "AENOR - Douro Interior S.A.”, now “Ascendi Douro, Estradas do Douro Interior, S.A." (Ascendi, 2015), and it was concluded in 2012 (Ascendi, 2015). The decision to build the infrastructure was supported by economic studies made in 2008: KPMG/VTM (2008) and Reis et al. (2008). Despite these studies, some political sectors expressed their skepticism about the benefits of the infrastructures whose construction was planned to start in 2008 and 2009, and criticised the costs that they would entail to the taxpayers. 
Nowadays, there seems to be some signs that traffic volume has been below what was expected in 2008. This probably means that the project benefits are also lower than previously expected. One justification for a lower traffic volume can possibly be found in the economic and financial crisis that has affected Portugal.

Godinho and Dias (2012) evaluated the postponement option concerning this infrastructure, based on the same data that was used by KPMG/ VTM (2008) and Reis et al. (2008). A simulation analysis performed by the authors confirmed that the expected benefits were larger than the expected costs. However, by taking into account the uncertainty concerning GDP changes and fuel prices, and by using real options analysis, the authors concluded that the expected net social benefit would be maximized by waiting until some of the uncertainty was resolved. This result raises methodological questions concerning the way benefit-cost analysis has been conducted, and makes us wonder whether its conventional application is sufficient for achieving robust conclusions.

In this paper, we will try to give insights into some methodological issues by answering some questions:

- What influence did the crisis have in the economic evaluations, comparing the analysis made in 2008 with the analysis made in the light of what is known today?

- If the current macro-economic situation (early 2015) had been anticipated at the time, would the recommendation given by the studies be different?

- What methodological lessons can be learned from this case?

The rest of the paper is structured as follows. In the next section we outline the main components of cost-benefit analysis considered in this study. In sections 3 and 4, we present the changes that result from updating macro-economic variables, and their impact on the components of Cost-Benefit Analysis. In section 5, we report the results, and we present the conclusions in section 6 . 


\section{The Components of Cost-Benefit Analysis (CBA)}

CBA is a crucial tool for determining the project economic viability (Afonso, 2013; Reis et al., 2008), and it was the methodology used in the economic analysis made in 2008, regarding the Douro Interior Infrastructure. In what follows, we will detail the main options that were considered in the CBA, describing the main benefits and costs, and the way they were quantified. The direct net benefits estimated in those analysis concerned mainly three groups of stakeholders:

- Infrastructure Managers;

- Users;

- Society.

The direct net benefits assumed for the infrastructure managers were, as it is usual in the case of road infrastructures:

- Construction costs (initial costs): initial investment related to pavement construction, including expropriation costs (Reis et al., 2008);

- Maintenance and operation costs: all activities that occur throughout pavement life cycle in order to keep its quality above a required threshold;

- Residual value (considered as a negative cost or a benefit): present value of the road infrastructure considering its use beyond the horizon of analysis, based on its structural and functional value.

The direct net benefits considered for the users were:

- Value of travel time: travel time savings, quantified according to recommendations from the HEATCO project regarding Portugal (Bickel et al., 2006);

- Vehicle operating costs: both fuel and nonfuel costs were considered. These costs depend essentially on travelled distance, driving speed and fuel prices, according to Department for Transport (DfT) (2009);

- Benefits associated to new users: some users will travel due to the availability of the new infrastructure. 
The impact to society includes both direct and indirect effects:

- Accident casualties: costs of fatalities and injuries (serious and light injuries), and property damage, quantified according to recommendations from the HEATCO project regarding Portugal (Bickel et al., 2006);

- Air pollution emissions: emission of pollutants that affect public health, the buildings, the ecosystem and risks associated with the environment, quantified according to the recommendations of HEATCO project regarding Portugal (Bickel et al., 2006);

- Wider economic benefits: improved labour supply and increased output in imperfectly competitive markets, measured indirectly according to the recommendations of DfT (2005).

No tolls were applied in this infrastructure, so tolls were not considered in the CBA. According to Reis et al. (2008), the net impact of noise was negligible, so it was not included in the analysis. The specific quantitative information regarding the infrastructure was gathered from KPMG/VTM (2008), KPMG (2008) and Reis et al. (2008).

\section{Incorporation of the impact of macro-economic changes}

The original studies concerning this infrastructure are KPMG/VTM (2008) and Reis et al. (2008). Both studies assumed a time horizon of 30 years for the analysis, from 2009 to 2038, and the macro-economic assumptions were based on the information available in 2008 and forecasts produced by national and international institutions at that time. These studies considered the same data regarding the construction, operation and use of the infrastructure (traffic volume and construction costs, for instance), and similar macro-economic settings, presenting some differences in the methodological choices made. This results in different but similar estimated Economic Net Present Value (ENPV): KPMG/VTM (2008) estimate an ENPV of 261 million euros and Reis et al. (2008) estimate an ENPV of 225 million euros. In this paper we follow mostly the methodological choices of Reis et al (2008). 
The economic environment turned out to be very different from what was expected at the time. We want to assess how these differences impact the results of the previous studies. In order to do so, we will consider recent macro-economic data (as of January 2015) and assess its impact on the ENPV. We will now briefly describe the variables whose values are adjusted, and outline their impact.

\section{Gross Domestic Product (GDP)}

GDP influences directly and significantly several components of the CBA: value of travel time, environmental costs, accident costs and wider economic benefits. Apart from this direct influence, changes in GDP will also be reflected in other components, probably even more important than the ones already cited: GDP will have an impact on traffic, which is an essential driver of the value of many benefits. The evolution of GDP since 2008 has been much worse than what was expected at the time, contributing to a decrease in the ENPV.

To use updated GDP data, values from 2009 to 2013 were gathered from PORDATA (2014). International Monetary Fund (IMF) forecasts were used for the 2013 to 2019 period (IMF, 2015). As there were no forecasts available for the rest of the time horizon, a constant GDP growth rate was considered, equal to the one defined by the IMF for 2019.

\section{GDP disparity}

GDP disparity for the region in which the infrastructure is located (Douro Interior) in relation to the whole country is taken into account in the analysis. The average per capita GDP for the Douro Interior region is lower than the national average, leading to smaller economic benefits of the infrastructure.

In Reis et al. (2008) it was considered that the Douro Interior per capita GDP was $68,0 \%$ of the national average. The updated available information from the Instituto Nacional de Estatística (INE, 2014a) leads to values of $70,0 \%$ and $71,9 \%$ for 2012 and 2013, respectively. In the present study we assumed an average per capita GDP of the Douro Interior region remaining at $71,9 \%$ of the national average for the rest of the time horizon. 
Changes in GDP disparity have an impact on the value of travel time and on the wider economic benefits. Since disparity was reduced and, therefore, the per capita GDP of the region is now a larger percentage of the corresponding national value, this will contribute to an increase of the ENPV due to a larger valuation of time savings and wider economic benefits.

\section{Fuel prices and non-fuel operation costs}

Petrol and diesel are the types of fuel used by almost all road vehicles in Portugal, and so they were the only two type of fuels considered in the analysis. Fuel prices have a direct impact on users' operation costs and also an indirect impact on different components of the CBA, through their impact on traffic (if fuel costs increase, some users will stop using the infrastructure).

Reis et al. (2008) assumed constant fuel prices before taxes, equal to the average of their values in the 12 months previous to the analysis (from October 2007 to September 2008), as reported by the Direcção Geral de Energia e Geologia (DGEG). KPMG/VTM (2008) do not report the assumed fuel cost, but they use constant vehicle operation costs per unit of distance, implying that constant fuel prices were assumed. In this paper, we will update these values using annual data available until 2014 (DGEG, 2015). Beyond 2014 we assume a constant price, equal to the 2014 average price.

Value-added tax (Imposto sobre o Valor Acrescentado, IVA) and tax on oil products (Imposto Sobre Produtos Petroliferos, ISP) are indirect taxes, so their direct impact is removed from the economic analysis. However, these taxes are paid by users, so they impact their decisions concerning the use of the infrastructure, and also provide some indications in relation to the value of the perceived benefits. For IVA, previous analysis considered a constant rate of $20 \%$ and for ISP the values prevailing in 2008 were also assumed to be kept constant throughout the analysis.

IVA and ISP will only have an impact after the infrastructure starts being used. This means that their values will only be relevant for time periods when at least some road sections are already opened to traffic (2011 and 
beyond). In 2011, IVA has changed from $20 \%$ to $23 \%$, so in this paper a constant rate of $23 \%$ is considered. We notice that, apart from its impact in fuel prices, IVA is also considered in the non-fuel operation costs.

ISP values were also updated, according to the information from DGEG (DGEG, 2015). Values of ISP are available up to 2014, and they were assumed to remain constant afterwards.

Both fuel prices and taxes on both fuel and non-fuel costs increase in comparison with the initial analysis. This will lead to a direct increase in operating prices and, more significantly, a decrease in traffic. Both these aspects will contribute to a decrease of the ENPV.

\section{Wages as percentage of GDP and total tax revenue as a percent- age of GDP}

Wages as percentage of GDP, and total tax revenue as a percentage of GDP, have an impact on the wider economic benefits of the infrastructure.

Wages as percentage of GDP were updated, up to 2013, using values from INE (2014b). After 2013, we assumed a constant value, equal to the value corresponding to 2013. Tax revenue as a percentage of GDP was gathered from OECD (2014). Values up to 2012 were available and, for later years, we assumed values equal to the percentage corresponding to 2012 .

Both these variables had lower values than the ones assumed in the initial studies. The specific impact of these variables, as measured in the wider economic benefits, concerns the additional entries to the labour market, and while a reduction in the wage to GDP ratio will tend to increase the benefit, a reduction in the tax to GDP ratio will tend to decrease it. The resulting impact is, therefore, undefined.

\section{Average load of heavy vehicles}

The benefits of the infrastructure for heavy vehicles will depend on the average load of such vehicles. We updated the value of this average load, using data from INE for the years 2012 (INE, 2013) and 2013 (INE, 2014c). For the following years, we assumed a constant value equal to 2013. 
The values we gathered were greater than those that had been assumed in the previous studies, leading to an increased benefit of travel time savings for heavy vehicles, and also to an increase in wider economic benefits. Consequently, this will contribute to an increase in ENPV. However, some caution is necessary in considering this impact, since we did not consider that a larger load may mean that fewer heavy vehicles will use the infrastructure. In a sensitivity analysis we consider the case in which the average load is unchanged.

\section{Wages, wage taxes and unemployment rate}

Wages have an impact on both the construction costs and the costs of maintaining and operating the infrastructure. Wage taxes and unemployment rate have an impact on the determination of the costs of labour, according to the methodology proposed by the European Commission (EC, 2008).

In the analysis of Reis et al. (2008), a different treatment was given to labour costs, depending on whether the corresponding jobs were created by the project or not. In the case of the labour used for building the infrastructure, it was considered that those jobs were not created by the project, and the cost of the corresponding wages was not adjusted: the underlying assumption is that those workers would be working somewhere else if they were not in the project.

In the case of jobs created by the project - the labour costs for maintaining and operating the infrastructure - Reis et al. (2008) assumed that those jobs would not exist without the infrastructure, and the approach presented by EC (2008) for calculating shadow wages was followed. According to this approach, taxes and social security payments should be used to adjust the cost of labour and, when there is high involuntary unemployment (more than 15\%-20\%), the unemployment rate should also be used to adjust the cost of labour. In this approach, the shadow wage rate is calculated as:

$$
S W R=W(1-u)(1-t)
$$

Where $S W R$ is the shadow wage, $W$ is the market wage, $u$ is the unemployment rate and $t$ is the rate of social security payments and relevant 
taxes. In EC (2008) it is also noticed that, unless there is high involuntary unemployment, the above expression will understate the cost of labour. Taking this into account, and considering that the unemployment rates in 2008 were well below 15\% (and a significant rise was not expected), Reis et al. (2008) only considered a conversion factor regarding the rate of social security payments and relevant taxes ( $u$ was considered equal to zero).

In this paper, we follow an approach similar to Reis et al. (2008). However, we take into account that there was a significant rise in unemployment in Portugal, exceeding $15 \%$ in some years, so we also include the unemployment rate in the determination of the shadow wage rate for the labour created by the project.

Both in the case of labour used to build the infrastructure and labour used for its operation and maintenance, we make a correction to the wages, in order to take into account the changes in real wages occurred in Portugal. A zero growth rate in real wages had been assumed in the previous studies, meaning that wages were expected to increase at the same rate as the inflation. In this paper, we use the nominal wages reported by PORDATA (2015) to calculate the growth of real wages until 2012. In some of the years, we can observe a negative growth in real wages. For future years, we assumed that the real wage would be kept constant (that is, that it would rise at a rate equal to inflation).

For the labour used to operate and maintain the infrastructure, we updated the rate of social security payments and relevant taxes, and we incorporated unemployment in the analysis. For wage taxes and social security payments, we used data until 2013 available from OECD (OECD, 2014) and we assumed that the wage percentage corresponding to such contributions would remain constant thereafter. For unemployment, we used the national unemployment rates available from 2009 to 2014 from INE (2014b, 2015), and forecasts from 2015 to 2019 from the IMF (2015). Beyond 2019, we assumed a constant unemployment rate equal to the 2019 forecast.

Comparing the updated values to the forecasts used in the previous studies, wages are lower and both the unemployment rate and the wage 
taxes and social security payments are higher. This leads to a reduction of the cost of labour, contributing to an increase of the ENPV. In order to get a better picture of the impact of the unemployment rate on the results, we will also perform a scenario analysis, considering the cases in which the unemployment rate is not considered in the shadow wage rate, and also the case in which a different evolution is considered for this variable.

\section{Adjustments to traffic forecasts}

Original traffic forecasts were made for a given scenario of GDP and fuel prices. Since there were important changes in these variables, it was necessary to analyse how these changes would impact the forecasts. This analysis is particularly important since traffic is generally the most important variable determining the benefits in a CBA of a road infrastructure (Godinho \& Dias, 2012), due to its impact on the most important components of the CBA.

In order to re-estimate traffic volume, we took into consideration the traffic estimates used by Reis et al. (2008) and KPMG/VTM (2008) and also the original GDP values and fuel prices assumed by traffic consultants, as gathered from (KPMG/VTM, 2008). The traffic was then calculated based on the updated GDP and fuel costs (as described in the previous section). We also used estimates of traffic elasticity in response to the GDP and fuel prices, as reported by Silva and Caetano (2013). These authors estimate different elasticities for different NUTS III national regions and, for the Douro Interior, they report traffic elasticities of 0,865 in response to GDP and $-0,587$ in response to fuel prices.

The estimation of traffic changes was made separately for each type of fuel and for the light and heavy vehicles. This means that we ended up having also a new distribution of vehicles in the infrastructure.

Taking into account the revised GDP and fuel price values, as well as the previous elasticities, we obtained a reduction in the estimated traffic. This will contribute to a substantial decrease in the ENPV. 


\section{Results and analysis}

After making all the adjustments to the model used in previous studies, and taking the methodology of Reis et al. (2008) as the main reference, we will now analyse the impact of the changes in the CBA results. We will analyse this impact for each CBA component, and compare our results with those of KPMG/VTM (2008) and Reis et al (2008), as shown in Table 1.

Similarly to the previous studies, we used a discount rate of $4 \%$ (defined by Despacho $n^{\circ} 13$ 208/2003, 25 June, Ministry of Finance). We can argue that, at least at the peak of the crisis, a larger rate would be justifiable. However, this rate is defined by the Government and remained unchanged for the whole period. We obtain a negative ENPV: -43 million euros. The Economic Rate of Return (ERR), the rate that produces a zero value for the ENPV, is 3,5\%, less than half the value obtained by KPMG/VTM (2008) and well below the value of $6,3 \%$ obtained by Reis et al (2008).

Table 1: Comparison of the results obtained with the updated macro-economic values with those of the previous studies.

Unit: million euros

\begin{tabular}{|l|ccc|}
\hline \multicolumn{1}{|c|}{ Components of ENPV } & $\begin{array}{c}\text { (KPMG/VTM, } \\
\text { 2008) }\end{array}$ & (Reis et al., 2008) & $\begin{array}{c}\text { Updated } \\
\text { values }\end{array}$ \\
\hline Travel time savings & 470,5 & 590,2 & 400,6 \\
Vehicle operating costs & 23,5 & 1,0 & 0,1 \\
\hline Accident costs & 112,2 & 159,0 & 99,7 \\
Environmental externalities & $-1,0$ & $-3,2$ & $-2,2$ \\
Benefits related to new users & 126,2 & 34,3 & 22,5 \\
Wider economic benefits & NC & 45,9 & 31,4 \\
\hline Construction, maintenance and & $-531,5$ & $-688,6$ & $-680,2$ \\
operation costs & 51,1 & 86,1 & 85,4 \\
Residual Value & $\mathbf{7 3 1 , 3}$ & $\mathbf{9 1 3 , 4}$ & $\mathbf{6 3 7 , 4}$ \\
\hline \multicolumn{2}{|c|}{ NPV of economic benefits } \\
NPV of economic costs
\end{tabular}

The reduction of GDP plays an important role in the reduction of ENPV, since the crisis led to GDP values that are lower than expected 
in 2008 and GDP has an impact on several components of the CBA. The reduction of estimated traffic due to the GDP reduction and to the increase in fuel prices (in several years, traffic was reduced by more than $20 \%$ ), also had a clear impact on the reduction of the ENPV.

Separately analysing the different components of the CBA, and comparing the values now obtained with those of Reis et al (2008) (which has a methodology closer to ours), we notice very significant decreases in the net benefits associated to travel time savings and accident costs and also some important decreases in the benefits related to new users and in the wider economic benefits, induced by the decrease in traffic. In the case of accident costs we must notice that, since most of the traffic is base traffic, and a decrease in such traffic occurs both with and without the infrastructure, it should be expected that such a decrease would also lower the benefits associated with a reduction in accident costs.

The reduction of traffic also leads to a very small decrease in the net costs of environmental externalities, but the impact is only marginal. The changes related to labour market, namely the reduction in wages and the increase in unemployment, lead to a reduction in construction, maintenance and operation costs, but the impact is small.

We must also notice that, although the two studies made in 2008 have performed a sensitivity analysis on the variables that were considered critical, they did not foresee a negative ENPV as calculated in the present analysis. The macro-economic impacts of the crisis that occurred in Portugal were too deep to be captured by the analysis made at the time.

We conclude that changes in macro-economic variables have as net effect a very significant reduction in the ENPV, which becomes negative therefore, the change in the macro-economic situation is enough to turn an infrastructure that was expected to provide significant net economic and social benefits into an economic and social liability.

We must acknowledge that the incorporation of some updates in the analysis might have been made in different ways - for example, different assumptions might have been considered for the future values of fuel prices and unemployment rate, and different assumptions might have been considered for the impact of changing the average heavy vehicle 
load. In order to take this into account, we made a sensitivity analysis for the fuel prices, and considered different scenarios for the unemployment rate and heavy vehicle load.

In the case of fuel prices, we considered values $10 \%$ above and $10 \%$ below the base scenario of our analysis (Table 2). For the unemployment rate, we analysed the impact of excluding it from the analysis (considering full-employment as in the previous studies) and we also analysed the impact of assuming that from 2019 on it will decrease, at a rate of $10 \%$ a year, until it reaches $7 \%$ - the average value of the unemployment rate for the period of 2000-2010 (see Table 3). Finally, for heavy vehicle load, we considered an alternative scenario in which its value is the one assumed by Reis et al. (2008) (Table 4).

Table 2: Sensitivity analysis for fuel prices

\begin{tabular}{|c|c|c|c|}
\hline \multirow{2}{*}{$\begin{array}{l}\text { CBA Components } \\
\text { Unit: ENPV in million euros }\end{array}$} & \multirow{2}{*}{$\begin{array}{c}\text { Base } \\
\text { scenario }\end{array}$} & \multicolumn{2}{|c|}{ Fuel price } \\
\hline & & $+10 \%$ & $-10 \%$ \\
\hline Travel time savings & 400,6 & 388,6 & 413,8 \\
\hline Vehicle operating costs & 0,1 & $-0,8$ & 1,0 \\
\hline Accident costs & 99,7 & 96,7 & 103,1 \\
\hline Environmental externalities & $-2,2$ & $-2,2$ & $-2,3$ \\
\hline Benefits related to new users & 22,5 & 22,6 & 22,6 \\
\hline Wider economic benefits & 31,4 & 30,4 & 32,4 \\
\hline Residual Value & 85,4 & 85,4 & 85,4 \\
\hline Total benefits & 637,4 & 620,7 & 655,8 \\
\hline Construction, maintenance and operation costs & $-680,2$ & $-680,2$ & $-680,2$ \\
\hline Total Costs & $-680,2$ & $-680,2$ & $-680,2$ \\
\hline ENPV & $-42,8$ & $-59,5$ & $-24,3$ \\
\hline ERR & $3,5 \%$ & $3,3 \%$ & $3,7 \%$ \\
\hline $\mathrm{B} / \mathrm{C}$ ratio & 0,94 & 0,91 & 0,96 \\
\hline
\end{tabular}

In the case of changes in fuel prices, there are some changes in the ENPV, but it always remains negative. In the cases of the unemployment rate and heavy vehicle load, the changes in ENPV are negligible.

We can reach the conclusion that the recent changes in the macro-economic situation in Portugal lead to an ENPV of the Douro Interior sub-concession that is negative. Godinho and Dias (2012) had already concluded that a significant positive ENPV, as provided by previous analysis, could not be enough to ensure that the best option would be to start 
building the infrastructure right away. These authors use the same data of Reis et al. (2008) and apply a model in which GDP and fuel prices follow stochastic processes estimated from historical data. The authors use Monte Carlo simulation and reach a sizeable expected ENPV of 232 million euros, in line with the studies made in 2008. Using real options analysis the authors conclude that, in spite of this large ENPV, the expected ENPV would be maximized if the decision to postpone the project was made, in order to resolve some uncertainty, instead of starting building right away. The authors only considered uncertainty in GDP and fuel prices - it is possible that the inclusion of other sources of uncertainty would reinforce this conclusion.

Table 3: Scenario analysis for unemployment rate

\begin{tabular}{|c|c|c|c|}
\hline \multirow{2}{*}{$\begin{array}{l}\text { CBA Components } \\
\text { Unit: ENPV in million euros }\end{array}$} & \multirow{2}{*}{$\begin{array}{c}\text { Base } \\
\text { scenario }\end{array}$} & \multicolumn{2}{|c|}{ Unemployment rate } \\
\hline & & $\begin{array}{c}\text { Decreases until it } \\
\text { reaches } 7 \%\end{array}$ & Excluded \\
\hline Travel time savings & 400,6 & 400,6 & 400,6 \\
\hline Vehicle operating costs & 0,1 & 0,1 & 0,1 \\
\hline Accident costs & 99,7 & 99,7 & 99,7 \\
\hline Environmental externalities & $-2,2$ & $-2,2$ & $-2,2$ \\
\hline Benefits related to new users & 22,5 & 22,5 & 22,5 \\
\hline Wider economic benefits & 31,4 & 31,4 & 31,4 \\
\hline Residual Value & 85,4 & 85,4 & 85,4 \\
\hline Total benefits & 637,4 & 637,4 & 637,4 \\
\hline $\begin{array}{l}\text { Construction, maintenance and } \\
\text { operation costs }\end{array}$ & $-680,2$ & $-680,3$ & $-680,8$ \\
\hline Total Costs & $-680,2$ & $-680,3$ & $-680,8$ \\
\hline ENPV & $-42,8$ & $-42,9$ & $-43,5$ \\
\hline ERR & $3,5 \%$ & $3,5 \%$ & $3,5 \%$ \\
\hline $\mathrm{B} / \mathrm{C}$ ratio & 0,94 & 0,94 & 0,94 \\
\hline
\end{tabular}

The results of this paper, and those of Godinho and Dias (2012), call into question the methodologies used in the evaluation of public projects, particularly those requiring sizeable investments. The identification and analysis of critical variables, as well as the use of Monte Carlo simulation, as prescribed by EC (2008), are clearly steps in the right direction. However, we must acknowledge that although real options theory has been widely researched in a corporate finance context, it has not been widely used for public projects evaluation. Real options theory has the 
potential to provide governments with the tools that lead to more robust decisions and, particularly, to the definition of contracts that contribute to maximize the social benefits while minimizing social risks. In the case of the Douro Interior sub-concession, a contract that structured the investment by stages, allowing the government to abandon later stages if the situation evolved differently from what was expected, might have minimized the risk associated with a downturn while allowing the construction to proceed if conditions were good.

Table 4: Scenario analysis for heavy vehicle load

\begin{tabular}{|c|c|c|}
\hline $\begin{array}{l}\text { CBA Components } \\
\text { Unit: ENPV in million euros }\end{array}$ & $\begin{array}{c}\text { Base } \\
\text { scenario }\end{array}$ & $\begin{array}{c}\text { Heavy vehicle load } \\
\text { Values of Reis } \text { et al. } \\
(2008)\end{array}$ \\
\hline Travel time savings & 400,6 & 397,7 \\
\hline Vehicle operating costs & 0,1 & 0,1 \\
\hline Accident costs & 99,7 & 99,7 \\
\hline Environmental externalities & $-2,2$ & $-2,2$ \\
\hline Benefits related to new users & 22,5 & 22,5 \\
\hline Wider economic benefits & 31,4 & 31,1 \\
\hline Residual Value & 85,4 & 85,4 \\
\hline Total benefits & 637,4 & 634,1 \\
\hline $\begin{array}{l}\text { Construction, maintenance and } \\
\text { operation costs }\end{array}$ & $-680,2$ & $-680,2$ \\
\hline Total Costs & $-680,2$ & $-680,2$ \\
\hline ENPV & $-42,8$ & $-46,0$ \\
\hline ERR & $3,5 \%$ & $3,5 \%$ \\
\hline $\mathrm{B} / \mathrm{C}$ ratio & 0,94 & 0,93 \\
\hline
\end{tabular}

\section{Conclusions and future research}

In this paper, we analysed the impact of a crisis in the economic evaluation of the Douro Interior sub-concession. In order to perform such analysis, we plugged the recent macro-economic data into the original studies performed in 2008. We conclude that the inclusion of these data would be enough to change the recommendation provided by the studies. So, if it would have been possible to forecast, in 2008, the current macro-economic situation, the decision would probably have been different. 
Our results, and also the results of previous studies like Godinho and Dias (2012), call into question the methodologies used for assessing large public projects. We show that unexpected changes in macro-economic conditions may turn a sizeable positive ENPV into a negative one, even if the original analysis was based in the best forecasts of macro-economic conditions, as the ones published by reputed international institutions. Additionally, since economic forecasts usually are not available for all the period of analysis, it is advisable to adopt a conservative attitude concerning the assumptions regarding macro-economic conditions.

We believe it is time to give real options models a more relevant role in the public sector. Real options models may help governments not only make better decisions but also define contracts that mitigate public risk. We intend to use real options models, similarly to Godinho and Dias (2012), to analyse the impact of considering other options in this infrastructure - namely the abandonment option and the options that would be available if the investment would have been staged as series of outlays.

It will also be interesting to make a qualitative ex-post analysis of the regional impacts of the infrastructure. Particularly, it may be useful to assess if the new infrastructure contributed for positive economic effects in its region. The objective would be to find indicators capable of evaluating the improvement of conditions for residents and regional development.

A further doubt stems from the evaluations of other concessions that were decided at the same time of the Douro Interior infrastructure. Would the conclusions reached in this paper be similar in the case of those other concessions?

Acknowledgments: This research was supported by Project EMSURE-Energy and Mobility for Sustainable Regions (CENTRO-07-0224-FEDER-002004)

\section{References}

Afonso, I. T. (2013). Análise Custo Benefício de Projectos Rodoviários. In Proceedings of $7^{\circ}$ Congresso Rodoviário Português. n. 136. 
Ascendi. (2015). Ascendi - Subconcessão Douro Interior. Ascendi. Retrieved January 14, 2015, from http://www.ascendi.pt/gca/?id=102

Bickel, P., Friedrich, R., Burgess, A., Fagiani, P., Hunt, A., Jong, G. D., ... Tavasszy, L. (2006). Developing harmonised European approaches for transport costing and project assessment (HEATCO). Deliverable 5: Proposal for harmonised guidelines. Institut für Energiewissenschaft und Rationelle Energieanwendung. Stuttgart, Germany.

Dft. (2005). Transport, wider economic benefits and impacts on GDP. London, UK.

DfT. (2009). Value of Time Operating Costs - TAG Unit 3.5.6. London, UK.

DGEG. (2015). Preços dos combustíveis líquidos. Retrieved January 7, 2015, from http:// www.dgeg.pt/?cn=6891700270037129AAAAAAAA

EC. (2008). Guide to cost-benefit analysis of investment projects: Structural funds, cohesion fund and instrument for pre-accession - Final report. Directorate General Regional Policy. Brussels, Belgium.

Ferreira, S. (2013). Parcerias Público-Privadas: A estimação da elasticidade preço da procura da A28. Tese de Mestrado em Economia e Gestão das Cidades, Universidade do Porto.

Godinho, P., \& Dias, J. (2012). Cost-Benefit Analysis and the Optimal Timing of Road Infrastructures. Journal of Infrastructure Systems, 18(4), 261-269. doi:10.1061/(ASCE) IS.1943-555X.0000105

IMF. (2015). World Economic Outlook Database, October 2014. Retrieved January 8, 2015, from http://www.imf.org/external/pubs/ft/weo/2014/02/weodata/index.aspx

INE. (2013). Estatísticas dos transportes e comunicações 2012. (Instituto Nacional de Estatística, Ed.). Lisboa: INE.

INE. (2014a). Anuário Estatístico da Região Norte 2013. Lisboa.

INE. (2014b). Anuário Estatístico de Portugal 2013. Lisboa.

INE. (2014c). Estatísticas dos transportes e comunicações 2013. Lisboa.

INE. (2015). Estatísticas do Emprego - 4. ${ }^{\circ}$ Trimestre de 2014. Lisboa.

KPMG. (2008). Estudo Económico a 75 anos com Actualização após Adjudicação — Projecto Douro Interior.

KPMG/VTM. (2008). KPMG/VTM. (2008). Estudo de Impacto Económico Global-Subconcessão Douro Interior.

OECD. (2014). OECD Factbook 2014: Economic, Environmental and Social Statistics. Paris: OECD Publishing.

Pereira, A. M., \& Andraz, J. M. (2007). Public investment in transportation infrastructures and industry performance in Portugal (No. 45). Journal of Economic Development (Vol. 32). The Economic Research Institute Chung-Ang University.

Pereira, A. M., \& Andraz, J. M. (2012). On the economic and budgetary effects of investments in SCUTS: the Portuguese toll-free highways. The Annals of Regional Science, 48(1), 321-338. doi:10.1007/s00168-010-0404-6

PORDATA. (2014). PIB e PIB per capita a preços constantes (base=2011) em Portugal. Retrieved December 18, 2014, from http://www.pordata.pt/Portugal/PIB+e+PIB+per+c apita+a+precos+constantes+(base+2011)-933

PORDATA. (2015). Salário médio mensal dos trabalhadores por conta de outrem da Construção: remuneração base e ganho por sexo - Portugal. Retrieved January 2, 2015, from http:// www.pordata.pt/Portugal/Salario+medio+mensal+dos+trabalhadores+por+conta+de+ou trem+da+Construcao+remuneracao+base+e+ganho+por+sexo-899 
Reis, J., Godinho, P., Barata, E., \& Cruz, L. (2008). Estudo Integrado dos Impactes Económicos Globais associados às Concessões da AE Transmontana, Túnel do Marão e Douro Interior (pp. 1-45). Coimbra.

Rosmaninho, G. P. (2010). A regulação dos operadores de infra-estruturas rodoviárias. Mestrado em Engenharia Civil, Universidade Técnica de Lisboa.

Silva, J. de A. e, \& Caetano, L. (2013). Determinantes da Evolução do Tráfego Rodoviário. Análise da sua Evolução em Portugal Continental. In Proceeding of $7^{\circ}$ Congresso Rodoviário Português. n. 128. 
Série Investigação

Imprensa da Universidade de Coimbra

Coimbra University Press

2015

mais

Programa Operacional Regional do Centro

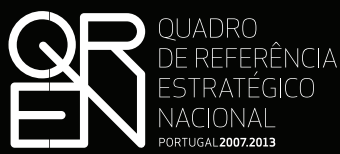

PORTUGAL 2007.2013

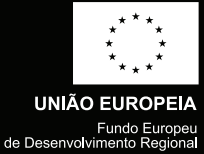

- $\mathbf{U}$

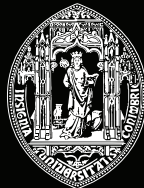

C •

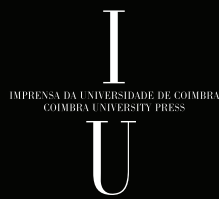

